\title{
RESUME
}

\section{Pengenalan Sistem Komputer}

Dea Rizkita Nanda

195120051

FAKULTAS KOMPUTER

dearizkitananda.student@umitra.ac.id

\section{Isi Resume :}

Sistem komputer adalah kumpulan dari elemen-elemen computer (hardware, software, brainware) yang saling berhubungan (terintegrasi) dan saling berinteraksi untuk melakukan pengolahan data dengan tujuan menghasilkan informasi sesuai dengan yang diharapkan. Dan tujuan pokok sistem komputer adalah untuk mengolah data untuk menghasilkan informasi.

Yang disebut dengan hubungan antar elemen sistem komputer adalah semua elemen berhubungan dengan yang lainnya.

\section{Fungsi Sistem Komputer :}

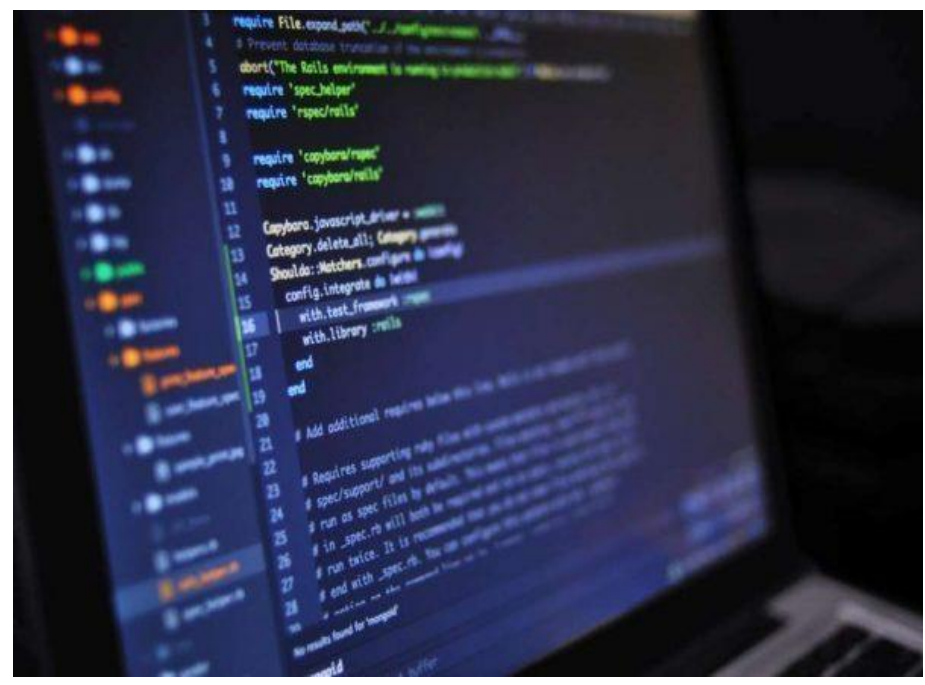

Sistem komputer memiliki peran yang sangat vital bagi berlangsungnya penggunaan komputer. Oleh karena itu, penting juga bagi kamu untuk mengetahui fungsi sistem komputer. Dengan mengetahui fungsi sistem komputer maka kamu akan tahu betapa pentingnya keberadaan sistem komputer ini. Berikut ini fungsi sistem komputer: 


\section{Input data}

Fungsi input merupakan fungsi memasukkan data dari penngguna ke komputer.jadi ketika pengguna memasukkan sebuah perintah, maka sistem akan bekerja untuk membuat perintah yang kamu masukkan sebagai data dapat di proses oleh komputer.

\section{Proses data}

Fungsi proses adalah dimana sistem mengolah data yang simasukkan ke dalam komputer. Jadi setelah data yang kamu masukkan diterima oleh komputer, maka komputer dengan segala sistem yang ada di dalamnya akan mengolah perintah yang kamu berikan.

\section{Menghasilkan data}

Fungsi ini setelah data di proses, sistem komputer akan mengahasilkan data baru dari data yang diproses tersebut. Fungsi ini merupakan fungsi lanjutkan dari proses pengolahan data. Jadi setelah data diolah oleh komputer, akan ada komponen lain yag menghasilkan data untuk ditampilkan.

\section{Menyimpan data}

Setelah data dihasilkan, selanjutnya data tersebut dapat disimpan agar bisa dibuka kembali lain waktu. Ini bertujuan untuk membuah data yang kamu masukkan aman dan masih bisa kamu gunakan di kemudian hari.

\section{Elemen/Komponen Utama Pada Sistem Komputer :}

Sistem komputer sendiri memiliki berbagai komponen utama yang sangat penting keberadaannya demi berjalannya sistem komputer yang baik. Tanpa keberadaan salah satu komponen utama ini tentu saja sistem komputer tidak akan bisa berjalan dengan baik. Maka dari itu, kamu juga perlu mengetahui komponen utama apa saja yang harus dimiliki suatu sistem komputer agar suatu sistem komputer dapat terwujud.

Elemen utama pada sistem komputer dibagi setidaknya menjadi tiga bagian. Berikut ini elemen utama yang harus dimiliki sistem komputer: 


\section{Brainware (User)}

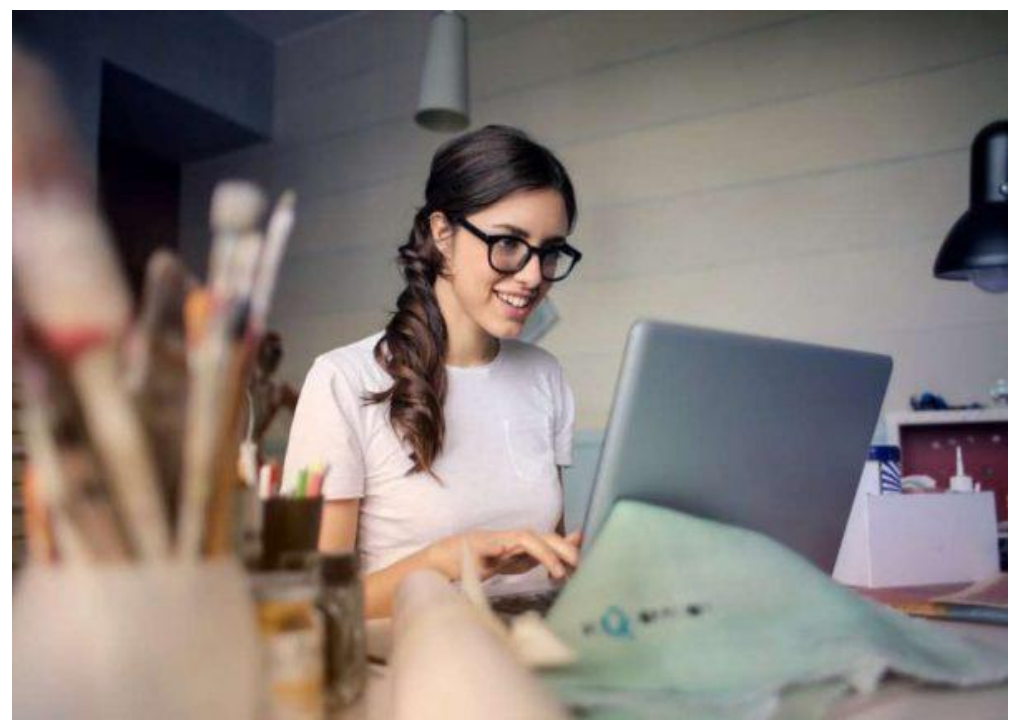

Brainware atau bisa kita sebut perangkat otak adalah manusia atau pengguna komputer itu sendiri. Brainware bisa pula disebut sebagai user. Jadi, ketika kamu menggunakan sebuah komputer maka sebenarnya kamu yang menjadi pengguna komputer itu sendiri juga menjadai bagian dari sistem komputer tersebut. Saat kamu mengetiki di Microsoft word, atau mungkin bermain game misalnya, maka kamu menjadi brainware dari komputer tersebut.

Maka dari itu, brainware secara sederhana bisa kita sebut sebagai pengguna komputer tersebut. Keberadaan brainware menjadi sangat penting karena tentu saja komputer tidak mungkin berjalan sendiri tanpa dioprasikan oleh pengguna.

\section{Hardware}

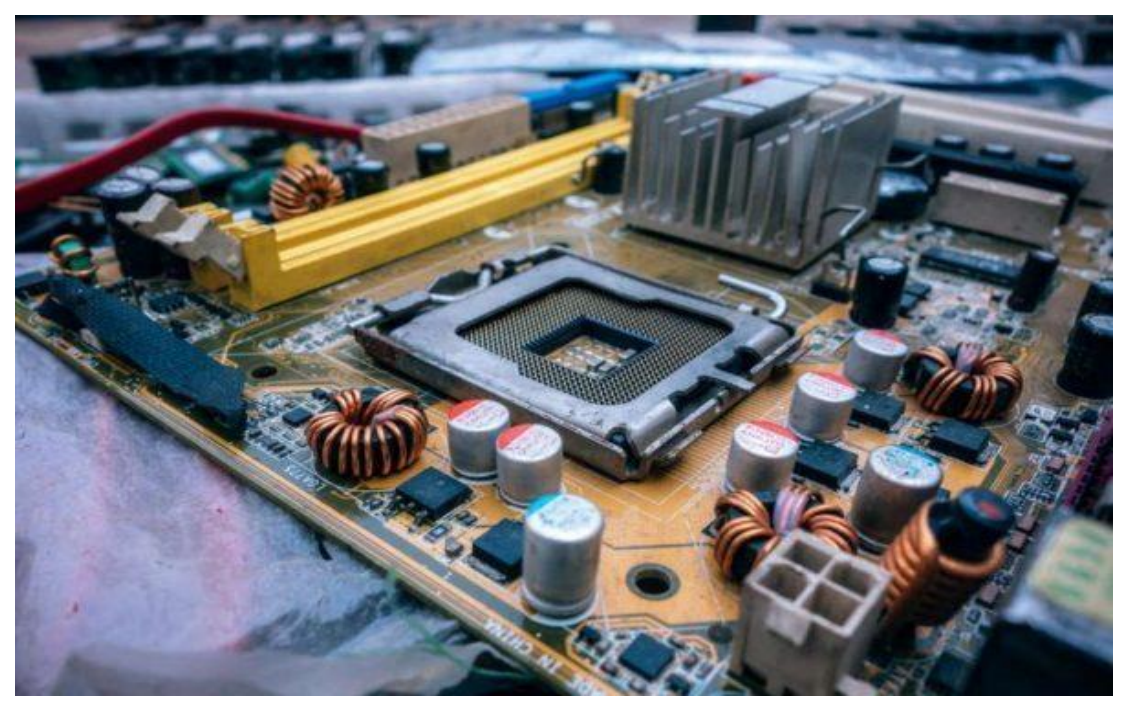


Hardware atau perangkat keras adalah perangkat yang memiliki wujud fisik. Perangkat ini adalah berbagai benda komputer yang anda gunakan. Misalnya monitor, mouse, keyboard, dan CPU. Semua komponen tersebut merupakan bagian dari elemen hardware komputer.

Hardware pada sistem komputer juga terdiri dari beberapa unit komponen, yaitu:

- Processing Unit (CPU)

Processing Unit atau CPU (Central Processing Unit) adalah perangkat keras komputer yang berfungsi sebagai pusat pengolahan data dan mengontrol semua perangkat internal ataupun eksternal yang terhubung pada komputer. Jadi bisa dikatakan perangkat ini merupakan otak dari komputer. CPU akan melakukan komunikasi dengan komponen input, output dan storage untuk melaksanakan data atau perintah yang di masukkan.

\section{- Input Unit}

Input Device adalah perangkat keras komputer yang memiliki fungsi sebagai alat untuk memasukan data atau perintah ke dalam komputer. Contohnya adalah:

1. Keyboard

2. Pointing Device

3. Mouse

4. Touch screen

5. Digitizer Grapich Tablet

6. Scanner

7. Microphone

\section{- Output Unit}

Output Device adalah perangkat keras komputer yang mempunyai fungsi untuk menampilkan informasi atau data yang merupakan hasil dari pemrosesan di sistem komputer. Data yang dihasilkan dapat berupa hard-copy (ke kertas), soft-copy (ke monitor), gambar, suara atau berupa video.. Contohnya antara lain adalah :

1. Monitor

2. Printer

3. Speaker

- Storage Unit

Instruksi yang telah dimasukkan pada sistem komputer melalui input unit selanjutnya akan simpan di unit storage sebelum benar-benar mengalami pemrosesan. Begitu juga dengan hasil dari data yang telah selesai diproses, data tersebut terlebih dahulu disimpan pada Storage Unit sebelum dipindahkan pada Output Unit. Storage Unit terbagi menjadi dua yaitu:

1. Internal Storage

2. External Storage 


\section{Software}

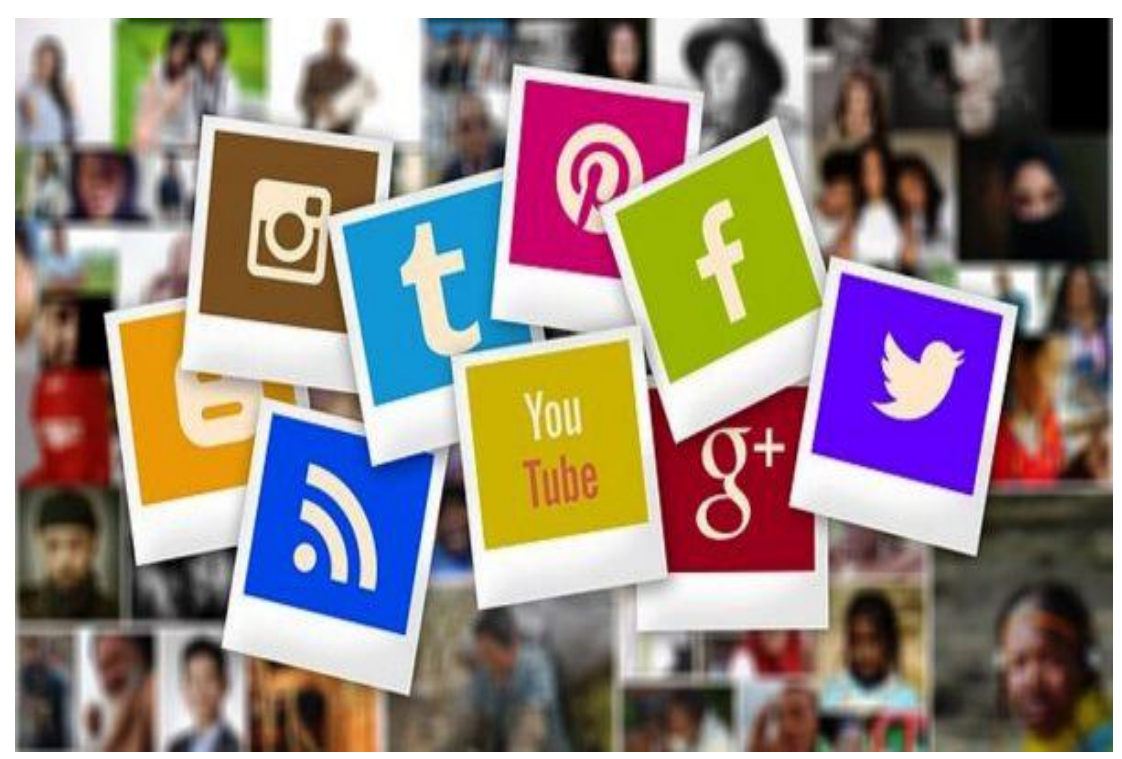

Software sendiri juga dikenal sebagai perangkat lunak. Disebut perangkat lunak karena tidak seperti hardware, software tidak memiliki bentuk fisik. Bisa dikatakan software adalah perangkat yang berisi perintah atau intruksi yang bisa dipahami komputer.

Software dapat dibedakan menjadi beberapa macam jenis kategori, misalnya seperti:

\section{Operating System (Sistem Operasi)}

Sistem Operasi komputer merupakan program dasar komputer yang berfungsi untuk menghubungkan pengguna dengan hardware. Bisa juga dikatakan sistem operasi adalah perangkat lunak yang memiliki tugas untuk melakukan kontrol perangkat keras yang memungkinkan terjadinya interaksi antara perangkat keras dengan jenis software yang lain. Contoh sistem operasi komputer misalnya: 1. Microsoft Windows

2. Linux

3. Mac OS

\section{> Program Aplikasi (Aplication Program)}

Program aplikasi adalah kategori software yang dipakai untuk membantu pekerjaan pengguna komputer untuk mengolah berbagai macam data. Perangkat lunak umumnya dinstall sesuai dengan kebutuhan pengguna komputer tersebut. Contoh adalah

1. Microsoft Excel

2. Microsoft Word

3. Microsoft Access

4. Photo Shop 
5. Web browser

6. Game dan masih banyak yang lain

\section{Utility Program (Program Tambahan )}

Utility Program atau software adalah software yang mempunyai fungsi untuk menjaga dan melindungi sistem komputer tetapi tidak berhadapan langsung dengan hardware. Contohnya antara lain:

1. Data recovery,

2. Disk Defragmenter

3. Sceensever

4. Backup

5. anti-virus dan lain-lain.

\section{Language Program (Bahasa Pemerograman )}

Language Program adalah bahasa yang dipakai oleh pengguna komputer untuk berkomunikasi dengan komputer, bisa juga dikatakan sebagai standar bahasa instruksi untuk berkomunikasi dan memberikan perintah pada komputer. Contoh bahasa pemrograman antara lain PHP, Java, Python dan lain-lain.

Akhirnya, lengkap sudah apa yang bisa saya jelaskan mengenai sistem komputer. Jika dilihat dari komponen penyusunnya, maka yang membedakan sistem komputer dengan komputer adalah user atau Brainware.

Jadi pada sistem komputer, kita sebagai pengguna masuk ke dalam sistem. Tanpa adanya perintah yang diberikan oleh pengguna, sistem komputer tidak akan bisa berjalan. 


\section{ID SECURITY}

QWTD44112377-ASP-524414475

\section{A. REFERENCE}

[1] O. M. Febriani and A. S. Putra, "Sistem Informasi Monitoring Inventori Barang Pada Balai Riset Standardisasi Industri Bandar Lampung," J. Inform., vol. 13, no. 1, pp. 90-98, 2014.

[2] A. S. Putra, "Paperplain: Execution Fundamental Create Application With Borland Delphi 7.0 University Of Mitra Indonesia,” 2018.

[3] A. S. Putra, "2018 Artikel Struktur Data, Audit Dan Jaringan Komputer," 2018.

[4] A. S. Putra, "ALIAS MANAGER USED IN DATABASE DESKTOP STUDI CASE DB DEMOS.”

[5] A. S. Putra, "COMPREHENSIVE SET OF PROFESSIONAL FOR DISTRIBUTE COMPUTING."

[6] A. S. Putra, "DATA ORIENTED RECOGNITION IN BORLAND DELPHI 7.0."

[7] A. S. Putra, "EMBARCADERO DELPHI XE 2 IN GPU-POWERED FIREMONKEY APPLICATION."

[8] A. S. Putra, "HAK ATAS KEKAYAAN INTELEKTUAL DALAM DUNIA TEKNOLOGY BERBASIS REVOLUSI INDUSTRI 4.0."

[9] A. S. Putra, "IMPLEMENTASI PERATURAN PERUNDANGAN UU. NO 31 TAHUN 2000 TENTANG DESAIN INDUSTRI BERBASIS INFORMATION TECHNOLOGY."

[10] A. S. Putra, "IMPLEMENTATION OF PARADOX DBASE."

[11] A. S. Putra, "IMPLEMENTATION OF TRADE SECRET CASE STUDY SAMSUNG MOBILE PHONE.”

[12] A. S. Putra, "IMPLEMENTATION PATENT FOR APPLICATION WEB BASED CASE STUDI WWW. PUBLIKLAMPUNG. COM.”

[13] A. S. Putra, "IMPLEMENTATION SYSTEM FIRST TO INVENT IN DIGITALLY INDUSTRY."

[14] A. S. Putra, "MANUAL REPORT \& INTEGRATED DEVELOPMENT 
ENVIRONMENT BORLAND DELPHI 7.0.”

[15] A. S. Putra, "PATENT AS RELEVAN SUPPORT RESEARCH."

[16] A. S. Putra, "PATENT FOR RESEARCH STUDY CASE OF APPLE. Inc."

[17] A. S. Putra, "PATENT PROTECTION FOR APPLICATION INVENT."

[18] A. S. Putra, "QUICK REPORT IN PROPERTY PROGRAMMING."

[19] A. S. Putra, "REVIEW CIRCUIT LAYOUT COMPONENT REQUIREMENT ON ASUS NOTEBOOK.”

[20] A. S. Putra, "REVIEW TRADEMARK PATENT FOR INDUSTRIAL TECHNOLOGY BASED 4.0."

[21] A. S. Putra, "TOOLBAR COMPONENT PALlETTE IN OBJECT ORIENTED PROGRAMMING."

[22] A. S. Putra, "WORKING DIRECTORY SET FOR PARADOX 7."

[23] A. S. Putra, "ZQUERY CONNECTION IMPLEMENTED PROGRAMMING STUDI CASE PT. BANK BCA Tbk.”

[24] A. S. Putra, D. R. Aryanti, and I. Hartati, "Metode SAW (Simple Additive Weighting) sebagai Sistem Pendukung Keputusan Guru Berprestasi (Studi Kasus: SMK Global Surya)," in Prosiding Seminar Nasional Darmajaya, 2018, vol. 1, no. 1, pp. 85-97.

[25] A. S. Putra and O. M. Febriani, "Knowledge Management Online Application in PDAM Lampung Province," in Prosiding International conference on Information Technology and Business (ICITB), 2018, pp. 181-187.

[26] A. S. Putra, O. M. Febriani, and B. Bachry, "Implementasi Genetic Fuzzy System Untuk Mengidentifikasi Hasil Curian Kendaraan Bermotor Di Polda Lampung," SIMADA (Jurnal Sist. Inf. dan Manaj. Basis Data), vol. 1, no. 1, pp. 21-30, 2018.

[27] A. S. Putra, H. Sukri, and K. Zuhri, "Sistem Monitoring Realtime Jaringan Irigasi Desa (JIDES) Dengan Konsep Jaringan Sensor Nirkabel," IJEIS (Indonesian J. Electron. Instrum. Syst., vol. 8, no. 2, pp. 221-232.

[28] D. P. Sari, O. M. Febriani, and A. S. Putra, "Perancangan Sistem Informasi SDM Berprestasi pada SD Global Surya," in Prosiding Seminar Nasional Darmajaya, 2018, vol. 1, no. 1, pp. 289-294. 
